\section{THE DAYLIGHT SAVING SCHEME.}

CONSIDERATION is again being given to the principle of ensuring the utilisation of a larger number of hours of daylight in the summer months by putting forward the hands of timepieces by one hour during a period made compulsory by legislation. It was announced a few days ago that, by order of the Federal Council in Germany, all clocks there will be put forward an hour at II p.m. on April 30, and put back an hour at I a.m. on October I. The French Chamber of Deputies has voted unanimously for a similar proposal, and a committee of the Senate has been appointed to consider it. Also, the Home Secretary stated in the House of Commons on April $I_{7}$. that the question of taking the same step here is receiving the attention of the Government.

It is possible that the committee of the French Senate will report against the adoption of the proposed alteration of standard time; and substantial reasons for doing so can be fcund in a critical survey of the whole subject presented to the Paris Academy of Sciences, on April Io, by M. Ch. Lallemand. The supposed advantages of the daylight saving scheme are examined and criticised, and the conclusion reached is strongly adverse to the proposed change. It is shown that many of the advantages claimed are illusory. In France more than four-fifths of the population in the open country and smaller towns regulate their habits by the sun rather than by the clock; foundries and factories running continuously over the twenty-four hours would be unaffected. On the other hand, the advantages of such a scheme have already been realised in a simpler manner in French schools, colleges, and barracks, where it has been customary for a long time to rise one hour earlier in the summer.

We have dealt with the daylight saving principle on many occasions and have stated the fundamental objections to it. The scheme originated with the late Mr. W. Willett; and his persistent advocacy of it led to the introduction of a Daylight Saving Bill in the House of Commons in I908. The Bill passed its second reading and was reported on favourably by a Select Committee, but it failed to reach the final stages in the House. It was re-introduced in the following year, when a Select Committee reported against it, and again it failed to pass. In IgII the scheme was once more brought before the House under the title of the Summer Season Time Bill, only to be dropped at the end of the session. This Bill provided that "Greenwich mean time, as used for the purposes of astronomy and navigation, shall not be affected"; but otherwise the legal times of the United Kingdom of Great Britain and Ireland were to be advanced by one hour on the third Sunday in April in each year and put back by the same amount on the third Sunday in September. Every spring since then the advocates of this legislative measure have renewed their activities in the Press; and this

No. 2426 , VOL. 97] year the circumstances of the war have given them an exceptional opportunity of stating their argument that great saving in fuel used for lighting would be effected by making the daylight saving scheme compulsory.

We do not propose to attempt again to explain why the scheme is fundamentally unsound and scientifically undesirable, but it may be worth while to state categorically some of the main objections to it. These are as follows :

(I) A very large part of the population of our islands already makes full use of the daylight available in the different seasons, by adapting their hours of work to the hours of daylight. This is the case in all agricultural districts, and also in the building, engineering, and other trades which cannot be carried on easily in artificial light. The proposed Act of Parliament would thus not effect any daylight saving in these occupations, and wherever artificial illumination is easy and convenient, working hours will always tend to be independent of the position of the sun.

(2) Practically all the civilised nations of the world use a system of time-reckoning based upon the Greenwich meridian, their times being so many hours or half-hours behind or in advance of Greenwich time. If a periodical change of the time-standards in various months by different countries became the fashion, chaos would take the place of the present orderly system. There would be a kind of game of general post at certain periods of the year, each nation taking the time of its next eastern neighbour. Our prime meridian, accepted by nations as regulating the time of the world, would be discarded by us for five months in every year, in total disregard of existing well-considered and well-established internatıonal relations.

(3) The scheme would be applied to the whole of Great Britain, though north of Edinburgh there is little real darkness for a couple of months in the summer. All places north of Edinburgh have twilight all night from the end of April to the end of July, and there would be no advantage whatever in calling nine o'clock ten during those months. When the effect of latitude upon the length of day is considered, little support can be found for including Scotland in the scheme. On account of difference of latitude, Scotland has already a natural extension of the daylight hours in the summer months without any need for legislation.

(4) The duration of daylight in the third week of April is quite different from that of the third week in September. The corresponding parts of the year as regards length of day are the third week of April and the third week of August, or the third week of March and the third week of September.

(5) As Greenwich mean time would continue to be used for times of sunrise, sunset, moonrise, lunar changes, tides, and other nhenomena of astronomy and navigation recorded in calendars and tables, the difference between this and clock- 
time would often lead to great confusion. Boattrains would run according to the mid-European time, but the tides would be stated in Greenwich mean time. In most seaport towns a time-signal is used for the convenience of vessels in port, and is also valuable to the public. Would the signal always be given according to Greenwich mean time, or would it mark the changed hour during certain months of the year? It would often be difficult for local bodies to decide whether the interests of navigators or those of the public ought to determine the hour at which the timesignal should be given. Lighting-up times would be in like confusion, for they are determined by the times of sunset, which belong to astronomy, whereas the times in use would be those of the Greenwich or mid-European meridians according to the period of the year.

(6) Artisans who have to be in workshops at 6 a.m. would begin work at what is really $5 \mathrm{a} . \mathrm{m}$., and therefore most of them would have to rise at about 4 a.m. This means that they would have to get up in the dark more than twice as often under the daylight saving scheme as they do now. The difference would be particularly noticed in the last month of the period. The six o'clock artisans would have to suffer the discomforts of additional darkness in the early morning in order that people who are asleep when they have done a quarter of a day's work may have additional daylight at the other end of the day.

(7) For several weeks of the period over which the proposed advance of time would be effective additional fuel would be consumed for heating in the early morning, and this amount, as well as the additional lighting required by many thousands of artisans getting up in the dark, is overlooked when the saving of artificial illumination at night is put forward as a plea for the adoption of the scheme. The heat meridian is about two hours after the light meridian; and possibly it has determined the customary timetable here, as it does the social arrangements of other countries of Europe, as well as in the Tropics.

(8) Though hundreds of corporations and councils have expressed their desire to have the I54 additional hours of daylight per annum promised by the scheme, not a single scientific society or other body with expert knowledge has supported it. The public may demand whatever legislation it pleases, without regard for the consequences; but, in the words of the Select Committee which reported upon the Daylight Saving Bill of 1909, "having regard to the great diversity of opinior upon the proposals of the Bill and to the grave doubts which have been expressed as to whether the objects of the measure can be attained by legislation without giving rise, in cases involving important interests, to serious inconvenience," it will be a pity if the circumstances of the war should lead Parliament to adopt a measure which has been twice rejected already after full discussion.

NO. 2426, VOL. 97$]$

\section{THE IMPERIAL INSTITUTE.}

THE Imperial Institute (Management) Bill, which received the Royal Assent on April 18, provides for the transfer of the property and management of the Imperial Institute from the Board of Trade (in which these were vested by the Act of I902) to the Colonial Office. Mr. Bonar Law, in a speech on the second reading in the House of Commons, explained that in view of the commercial reorganisation which would take place after the war the Government desired that the valuable work of the institute should be supported by a larger and more representative governing body, on which each of the Dominions, India, and the Crown Colonies would be :epresented, as well as the Colonial Office, the Board of Trade, the Board of Agriculture, and the India Office, whilst representatives of the commerce and industry of the United Kingdom would also be nominated on the executive council, which will consist of twenty-five members. Among the speakers at this stage, and afterwards in Committee, were Sir J. D. Rees, Sir John Jardine, and Colonel Yate, all of whom proposed increased representation of India, and Sir Philip Magnus, who asked for the appointment of representatives both of the Imperial College of Science and Technology and of the University of London.

It was announced that the member selected by the Committee of the Privy Council for Scientific and Industrial Research would be nominated by the Secretary of State for the Colonies, and that of the other ncminees of the Secretary of State one wculd be an Indian member in addition to Lord Islington, the Under-Secretary of State for India, which would give India five members in all.

The second reading of the Bill in the House of Lords was moved by Lord Islington, who fully explained the intentions of the Bill and spoke in high terms of the value of the work of the institute to the commerce of the Empire. Visccunt Milner supported the Bill, and expressed the hope that in future the institute would be better supported with funds to aid the extension of its important work, a view which was also expressed by Viscount Peel and Lord Sudeley. In Committee Lord Sudeley moved an amendment to make Ministers of the Dominions, Governors of Crown Colonies and Protectorates, and members of the Viceroy's Council in India when at home on leave, ex-officio members of the executive council. This was not accepted by the Government, who, however, agreed to invite the persons specified to attend the meetings of the executive council.

\section{THE SUN'S ROTATION.1}

$A \mathrm{~N}$ interesting contribution to the investigation A of the sun's rotation by the spectroscopic method has been made by Mr. J. B. Hubrecht in an extended discussion of a series of plates taken by him with the McClean equipment at

1 Annais of the Solar Physics Observatory, Cambridge. Vol. iii., Part i. The Solar Rotation in June, 191r, from Spectrographic Observations made with the McClean Solar Instruments. By J. B. Hubrecht. Pp. 77. (Cam bridge: At the University Press, 1915.) Price gs. net. 